\title{
Political-institutional barriers to energy access and efficiency in Tanzania: a case study of Mvomero District
}

\author{
Felichesmi S. Lyakurwa (1), Eliaza Mkuna (2) \\ (I) Department of Engineering Management Studies, Mzumbe University, \\ Tanzania \\ (2) Department of Economics, Mzumbe University, Tanzania
}

\begin{abstract}
Recently, energy access and efficiency have attracted much research interest due to their critical role in addressing the challenges of climate change and the country's social and economic development. The major question in this study is whether household energy demand can be influenced by government institutions and political systems which switch their preferences towards clean energy sources including renewable energy. The analysis revealed that government agencies are not well-coordinated when dealing with energy access and efficiency issues e.g., ward and village leaders are not always in agreement and lack common understanding of issues arising out of increasing energy supply and use of energy efficient appliances. In addition, households witnessed that despite their low level of income, they would have done better in terms of accessing quality and affordable energy had they been educated or informed about the need to shift from using wood to electricity for different social and economic activities. The study recommends that universities offer training, research and consultancy in the energy field to help raise awareness among communities of costs and benefits of using clean energy sources. The results therefore, provide useful and current information to policy making and energy planning institutions on the barriers to energy access and efficiency in order to help formulate remedial action.
\end{abstract}

Key words: political-institutional barriers, government leaders, energy access and efficiency

\section{Introduction}

Energy access and efficiency, particularly in developing countries, is a current issue of concern due to its critical contribution towards societies' response to the challenges of climate change, and socio-economic and energy security. OECD (20II), Bertrand et al. (2015), Hosier and Dowd (I987) documented that countries that improve energy efficiency and the supply of energy to households significantly reduce the need for investment in energy infrastructure. Moreover, it helps to limit fuel costs, increase competitiveness over other energy alternatives and increases energy affordability for low income households, while reducing global pollutants and improving the livelihoods of local people, especially the rural poor. The supply of safe and reliable energy to the community guarantees 
the effective participation of its members in a range of social and economic activities, including agro-processing, cooking, mechanization of agriculture, food preservation, education and health services (Reddy, 2000; World Bank 2017). The benefits of energy supply, which implies energy access, has pushed governments in developing countries to engage in various initiatives to create policies that integrate energy use and supply in all its dimensions. Despite such efforts, studies have shown that the roles played by political institutions in terms of exploiting the benefits of energy access and efficiency, are inadequate. This is especially the case for households, in rural areas of developing countries, including Tanzania.

Energy efficiency that is achieved through the proper selection and use of energy efficient appliances has been considered to be one of the main means of achieving reductions in energy requirements. The OECD (2014) documented that the tendency towards energy improvement through energy efficiency gains is often followed by a rebound effect which promotes the overall impact of the measures in terms of consumer energy demand. Thus, following previous studies by Sorrell et al. (2004), Jiang (2012) and IEI (2017), use of energy efficient appliances for different social and economic activities contribute significantly to the savings in household energy use, affordability and continued environmental improvements. Though energy efficiency has numerous benefits, the extent to which households in many developing countries use energy efficient appliances for cooking, lighting, heating and powering machines is not clear.

To date, household access to reliable, clean and affordable energy sources for different social-economic uses in Sub-Sahara African countries remains a substantial challenge. Even in those areas that have infrastructures to support electric power supply, households suffer from severe power rationing and frequent disruptions to energy supply With the exception of South Africa, the electric energy consumption per capita in Sub-Saharan Africa remains low at 6\% of the global average (Brew-Hammond, 20I0; Colenbrander et al., 2015). Surprisingly, most of the households which are connected to electricity in both urban and rural areas are have low to very low energy consumption rates; and when they do have high energy consumption rates the energy is used inefficiently (Kichonge et al., 20I5; Ismail and Khembo, 2015). To date, the energy supply in Tanzania is mainly provided by biomass that contributes more than $90 \%$ of the total basic energy supply in the country (IEA, 2013). For example, in the year 2007, the energy supply from petroleum products contributed $8 \%$, grid electricity I\% and renewable energy sources including solar PV and wind energy made up I\% (Kichonge et al., 2015; MEM, 20I2; Kabaka and Gwang'ombe, 2007). The International Energy Agency (IEA) (2014) documented the total electricity generation shares in the year 2012 to be mainly from natural gas $50.7 \%$, hydro-electric $28.6 \%$, oil products $20.1 \%$, biofuels $0.3 \%$ and solar PV $0.2 \%$. The energy demand projections have approximated electricity demand to reach 47.7 TWh in the year 2035 which is equivalent to an annual growth rate of approximately 8\% (MEM, 20I2; IRENA, 20I4).

Considering the projected increase in demand and consumption pattern of the country's energy mix, policy reforms to integrate clean energy consumption and ensure 
effective participation of political-institutions in educating households on the cost benefits of using sustainable energy are needed to overcome the challenges of reaching a sustainable energy future for all by 2030 . Despite the efforts made to formulate policies that promote the use of renewable energy sources, there has been a general lack in the provision of necessary information including the influence of energy and appliance prices, the quantity of energy required for various social and economic activities and role of political-institutions in improving energy access and efficiency. This kind of information is required by policy makers and planners so as to identify the scale of energy demand, pricing strategies and households' capacity to pay for energy bills, so that they can determine the energy investment needs of different parts of the country.

The Government of Tanzania recognizes the central role of energy access and efficiency in achieving the overall development goal of improving the livelihood of the community. High quality livelihoods, a strong and competitive economy and governance of natural resources including energy and water are given high priority because of their central roles in meeting the targets of the Tanzania Development Vision 2025, the National Strategy for Growth and Reduction of Poverty (NSGRP) as well as the Sustainable Development Goals (SDGs). The Tanzania National Strategy for Growth and Reduction of Poverty (NSGRP) points out that energy is critical for attaining NSGRP and Millennium Development targets and thus it is important for productive activities in industry, agriculture, transport, water supply and the provision of social services (IMF, 20II, pp. 48-55).

Tanzania's National Five Year Development Plan 2016/17-2020/2Idocumented that Tanzania is one of the low income countries of the world but with the available expertise and other resources, the country can expect to graduate from low to middle income country status by 2025 (URT, 20I6). Hence, access to clean, affordable and appropriate energy is key to the growth of the small and large scale economies of Tanzania. In this regard, scientific research that establishes the dominant factors behind household energy demand can help the Government's energy policy makers to make appropriate and timely decisions for potential investments in each kind of energy type (Lyakurwa and Mkuna 2017). Moreover, identifying current political-institutional barriers to household energy access and efficiency is critical in terms of understanding whether household demand can be influenced to switch their demand towards clean energy sources including renewable energy by government institutions and political systems .

Despite the efforts of the government of Tanzania to ensure household access to clean and affordable energy sources required for different social-economic activities, significantly raising the levels of access and efficiency is a challenge. This suggests the need for a study to determine whether all political institutions (i.e., political leaders and government officials of all levels) in the country have played their role in ensuring energy access and efficiency and, if yes, what the barriers in the process were. According to Weber (I997), Sorrell et al., (2004), there are three components to the barriers to energy access and efficiency improvements i.e., an objective obstacle (e.g., human activities, regulations), a subject obstacle (e.g., end users, supervisors, managers, politicians) as well as action hindrance (e.g., increase/decrease in the purchasing behavior or energy tax). 
Moreover, politico-institutional barriers can be further categorized into three categories i.e., political obstruction, conflicting guidelines in the government structure and lack of policy coordination (Harmelink et al., 2008; Bertrand et al., 20I5).

First, political obstruction represents the situation whereby actions of government leaders and key policymakers hinder efforts to implement energy access and efficiency plans. Such actions include lack of political backing of measures and legislation to improve energy access and efficiency (UN, 2015). Secondly, conflicting guidelines in the government structure refers to the existence of conflicting interests between different government departments in the country, for example a ministry dealing with economic growth and the one dealing with environmental protection might have different objectives and preferences with regard to the pace, nature, and extent of energy access and efficiency. In such a situation the department which has jurisdiction over the energy access and efficiency governance may have an impact on broader inter-department battles, as it can be in the power distribution between these departments (Bertrand et al., 2015). A third category of political-institutional barriers to energy access and efficiency relates to the failure and impairment national of policy coordination. Based on the three main categories of barriers to energy access and efficiency, establishing household perception of energy access and efficiency in the districts is critical for identifying concrete barriers to energy access and efficiency.

The remainder of the article is structured as follows; the next section gives an overview of data and methodology and is comprised of the study area, data collection and analysis methods. Next, the key results and discussion of findings are presented. First, the demographic and population characteristics of respondents are described. Second, an in-depth discussion of the awareness of the environmental impact of energy sources is presented, together with discussion about household perceptions of the political-institutional barriers to energy access and efficiency. The last part of the paper focuses on the conclusion and recommendations.

\section{Data and methodology}

\subsection{Study area}

This study was conducted in five villages randomly selected from the five wards of Mvomero district which is one of the six districts forming the Morogoro region in Tanzania. The district covers an area of 6,632.9 sq. kms and a population of 312,109 with an average household size of 4.3 (URT 2013). This study is conducted in Mvomero district because most households have a low level of income and depend entirely on traditional energy sources such as wood and charcoal for cooking, lighting and heating. The dependency on non-sustainable and inefficient energy sources might be an indication of the districts' failure to realise the goals of the National Strategy for Growth and Reduction of Poverty (NSGRP), the Millennium Development Goals (MDG), the Tanzania Development Vision 2025, as well as the Sustainable Development Goals (SDG) (URT, I999; URT, 2005; UNHABITAT, 2009). Thus, developing a method that can establish the political-institutional barriers as a triggering variable towards energy access and efficiency is critical. 
Structured questionnaires and interview guide questions were employed to collect primary data from a sample size (n) of 300 households residing in the selected villages i.e., 60 interviews were conducted in each of the five villages selected from the five wards of Mvomero district (with a total population of 77,000 (URT, 2012)). A member of the household, in particular the household head aged 18 years and above, was interviewed. Primary data collected focused on the key topics which aimed to address research objectives including the roles of government institutions in the area of use of renewable energy and efficiency, and also the challenges of renewable energy choices. Checklists were guided by key questions which aimed to gather different opinions from government leaders on issues relating to regulation, policy, practice, and government plans with regards to energy access. The Statistical Package for Social Sciences (SPSS) version I7 and Excel software's were used in the analysis to model the political-institutional barriers to energy access and efficiency.

The data were analyzed using five point-Likert scale techniques. Often five ordered response levels are used, although many psychometricians advocate using seven or nine levels; a recent empirical study found that data from 5-level, 7-level and ro-level items show very similar characteristics in terms of mean, variances, skewness and kurtosis after a simple transformation was applied (Dawes, 2008; Hartley and Betts, 20I0). That is why five point-Likert scales seem to be more appropriate for this study. The collected data was analyzed using preliminary and descriptive analysis. The preliminary analysis involved coding, cleaning and screening of data prior to analysis. The preliminary tests to check normality, outliers, internal reliability and multicollinearity were employed to justify reliability of the collected data for the analysis. Descriptive analysis was used to compute frequencies, mean, standard deviations and percentages based on the households' responses.

\section{Results and discussion}

3.1. Demographic information of respondents

Table I presents the demographic information of the respondents residing in the selected villages of the five wards of Mvomero district including Mzumbe, Mvomero, Hembeti, Mgeta and Dakawa. In this study, surveyed villages were selected based on their proximity to the village and district offices by which three were distant as compared to other two villages such that some villages are more urbanized than others. Despite the differences in level of urbanization, households in the surveyed villages rely to great extent on traditional energy sources, mainly firewood and charcoal, for cooking, lighting and heating. 


\begin{tabular}{|c|c|c|c|}
\hline Variable & Classification & No. respondents & Percentage (\%) \\
\hline \multirow[t]{2}{*}{ Gender } & Male & 132 & 44 \\
\hline & Female & I68 & 56 \\
\hline \multirow[t]{3}{*}{ Age } & $18-35$ & I45 & 48.3 \\
\hline & $36-55$ & 97 & 32.2 \\
\hline & $>55$ & 58 & I9.2 \\
\hline \multirow[t]{4}{*}{ Marital status } & Married & 220 & $73 \cdot 3$ \\
\hline & Single & 46 & $\mathrm{I} 5 \cdot 3$ \\
\hline & Widow & 17 & $5 \cdot 7$ \\
\hline & Divorced & I7 & $5 \cdot 7$ \\
\hline \multirow[t]{5}{*}{ Occupation } & Farmer & 216 & 72.0 \\
\hline & Public servant & I4 & 4.7 \\
\hline & Business person & 58 & 19.3 \\
\hline & Worker-private sector & 7 & 2.3 \\
\hline & Home keeper & 5 & $\mathrm{I} .7$ \\
\hline \multirow[t]{5}{*}{ Education } & Never attended to school & I8 & 6.0 \\
\hline & Primary school & 228 & 76.0 \\
\hline & O-level & $4 \mathrm{I}$ & 13.7 \\
\hline & Certificate/diploma & Io & $3 \cdot 3$ \\
\hline & Bachelor degree and above & 3 & I.O \\
\hline
\end{tabular}

Table 1: Respondents' demographic information.

The results revealed a slightly higher number of females I68 (56\%) compared to males 132 (44\%) for the households in the five wards of Mvomero district (Table I). The results are in line with the Tanzania census report of 2012 which indicated that in the Mvomero district the number of females is higher than males (URT 20I2). The age distribution of the household members in the district is: I8-35 with I45 (48.5\%), 36-55, with 97 (32.2\%) and 58 above 55 years old (I9.2\%). The results indicate the availability of youthful energetic people in the surveyed villages such that if they are empowered by ensuring access to reliable and affordable energy source they can substantially contribute to the district's social and economic development. Based on the researcher's observation in the surveyed villages, lack of access to reliable energy mainly electricity means that it is difficult for households to participate effectively in the social-economic activities including adding value to agricultural produce, processing crops prior to selling to markets and preserving fruits. For example, in the surveyed areas many machines are powered by diesel as there is no supply of electricity, which means that many villagers are not able to preserve their fruits, meats and vegetables.

The marital status of respondents revealed that out of 300 respondents, $220(73.3 \%)$ are married, 46 (15.3\%) are not married while $17(5.7 \%)$ of the respondents are either 
widowed or divorced. The study results from the multinomial probit model developed by Lyakurwa and Mkuna (2017) indicated insignificant relationship between households' marital status and choice of energy source for cooking, heating and powering machines. Also, respondents in the surveyed villages possess a varied occupation status including farmer $216(72 \%)$, public servant $\mathrm{I}_{4}(4.7 \%)$, businessman 58 (I9.3\%), working with the private sector 7 (2.3\%), home keeper 5 (I.7\%). Finally, households in the five wards have different levels of education from never having attended class I8 (6\%), primary school 228 (76\%), ordinary secondary $4 \mathrm{I}$ ( $\mathrm{I} 3.7 \%)$, certificate/diploma Io $(3 \cdot 3 \%)$ to University degree 3 (I\%). Looking at the literacy level of the citizens in the five wards it is clear that for many people primary education as the highest level they have attained This may well affect their understanding of critical issues with regard to the energy sector issues that arise from policy, regulation and bylaws formulations.

\subsection{Respondents' awareness on the environmental impacts of energy sources}

The study revealed that many household, village and ward leaders in Mvomero District have great understanding of possible environmental problems e.g., deforestation, desertification, prolonged drought, air and water pollution and loss of biodiversity which are caused by the use of both traditional energy source e.g., animal dung and wood, as well as renewable energy sources such as solar PV and hydroelectricity. For example respondents residing in Mgeta ward, admitted that there is significant environmental changes today compared to the early I980s whereby water was flowing from the mountains and valleys throughout the year. They added that the ward government initiated a program of planting trees in the mountains in the early I980s which are now used for various domestic activities and mainly for cooking. So in the absence of that initiative the situation would be worse. Therefore they are of the opinion that ward and village leaders should be more pro-active and sensitize the community on the cost-benefits of using energy sources in a sustainable way despite their low level of income. One way they proposed is to convene a village meeting, discuss and agree on the remedial actions to combat environmental degradation caused by dependence on wood for cooking and heating in the villages.

Figure I represents the respondents' understanding of the possible environmental impact of using energy sources e.g., wood, kerosene, charcoal, solar PV and electricity. Out of 300 respondents, 227 (75.7\%) agreed that they understand the impact, 64 (2I.3\%) respondents responded that there is no environmental impact caused by the use of energy source while 9 ( $5.7 \%$ ) admitted they know nothing about the environmental impact of using certain energy sources for cooking, heating and lighting. Though the majority understand the environmental effects of using traditional energy sources, government and private sector intervention is needed to complement government efforts so as to enhance the availability of renewable energy appliances in the market (sold at affordable prices) as well as educating households through different forums on the need for switching from traditional energy sources to modern ones. 


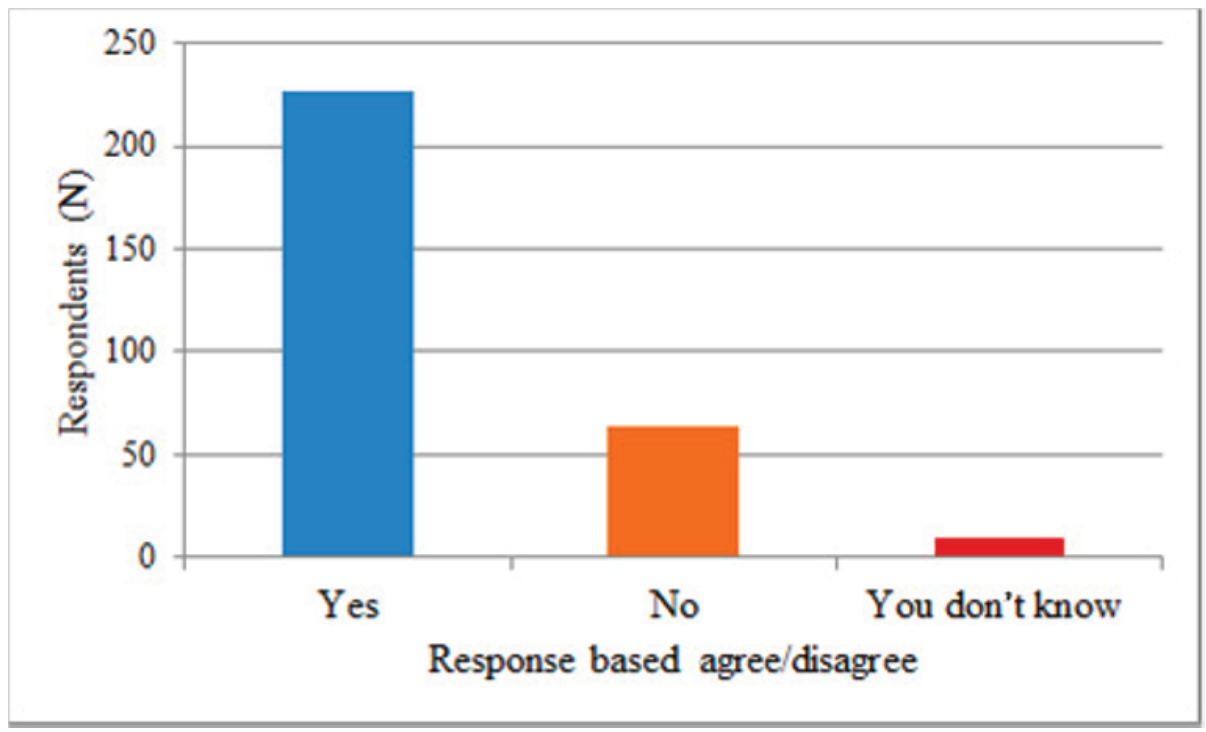

Figure 1: Awareness of respondents on environmental impacts of energy sources.

3.3. Households perceptions about barriers to energy access and efficiency

Table 2 presents the perceptions of households on the key factors hindering energy access and efficiency in the selected five wards of Mvomero district. 


\begin{tabular}{|c|c|c|c|c|c|c|c|c|c|c|}
\hline \multirow[b]{3}{*}{ Variable description } & \multicolumn{10}{|c|}{ Level of Agreement } \\
\hline & \multicolumn{2}{|c|}{ I } & \multicolumn{2}{|c|}{2} & \multicolumn{2}{|c|}{3} & \multicolumn{2}{|c|}{4} & \multicolumn{2}{|c|}{5} \\
\hline & $\mathbf{N}$ & $\%$ & $\mathrm{~N}$ & $\%$ & $\mathbf{N}$ & $\%$ & $\mathbf{N}$ & $\%$ & $\mathbf{N}$ & $\%$ \\
\hline $\begin{array}{l}\text { Current energy policy encourages } \\
\text { access and use of electricity e.g. } \\
\text { electric bill subsidy, reduce price } \\
\text { for connection and use. }\end{array}$ & 23 & $7 \cdot 7$ & 55 & 20.3 & 75 & 25.0 & 93 & 31.0 & 47 & I6 \\
\hline $\begin{array}{l}\text { Government plans and } \\
\text { instruments encourages switching } \\
\text { from wood fuel to renewable } \\
\text { energies such as solar PV. }\end{array}$ & 37 & $\mathrm{I} 2.3$ & 84 & 28.0 & 35 & II.7 & 86 & 29 & 57 & I9.0 \\
\hline $\begin{array}{l}\text { Village/ward leaders encourage } \\
\text { use of energy efficiency appliances } \\
\text { through different forums - radio, } \\
\text { television. }\end{array}$ & 103 & $34 \cdot 3$ & 89 & 29.7 & 52 & $17 \cdot 3$ & 49 & I6.3 & 6 & 2.0 \\
\hline $\begin{array}{l}\text { In the village/ward there are strict } \\
\text { rules/laws governing cutting } \\
\text { of tree for cooking/ burning of } \\
\text { charcoal. }\end{array}$ & 60 & 20.0 & 88 & $29 \cdot 3$ & 78 & 26.0 & $6 \mathrm{I}$ & 20.3 & Io & $3 \cdot 3$ \\
\hline $\begin{array}{l}\text { There is good coordination } \\
\text { between MP, Ward and village } \\
\text { leaders about energy access and } \\
\text { efficiency. }\end{array}$ & I09 & 36.3 & 65 & $2 \mathrm{I} .7$ & 57 & I9.0 & 59 & 20 & 9 & 3.0 \\
\hline $\begin{array}{l}\text { Energy efficient appliances are } \\
\text { easily accessed in the market } \\
\text {-solar panel, energy saving bulbs, } \\
\text { cooking stoves. }\end{array}$ & 36 & I2.0 & 62 & 20.7 & 50 & I6.7 & 105 & 35.0 & 46 & I6 \\
\hline $\begin{array}{l}\text { Households and other } \\
\text { stakeholders are involved in } \\
\text { energy investments. }\end{array}$ & 60 & 20.0 & 88 & $29 \cdot 3$ & 108 & 36.0 & 32 & I0.7 & II & $3 \cdot 7$ \\
\hline
\end{tabular}

Level of agreement: 1 = strongly disagree, 2 = disagree, $3=$ neither agree nor disagree, $4=$ agree, $5=$ strongly agree Table 2: Perceptions on barriers to energy access and efficiency.

The perceptions of households and ward/village leaders on critical factors hindering energy access and use of energy efficient appliances for different social and economic activities in the area revealed mixed results. The factors included government plans and policy, policy coordination, involvement of key stakeholders, as well as strict implementation of laws governing the cutting of trees used for burning charcoal (Table 2). The question of whether the current energy policy encourages access and use of electricity (indicated by the presence of electric bill subsidy, reduced price of electricity connection or free basic electricity to poor households) indicated that $23(7.7 \%)$ strongly disagree, $55(20.3 \%)$ disagree, 75 (25\%) neither agree nor disagree, 93 (31\%) agree and $47(16 \%)$ strongly agree. Based on the observations from the study area and respondents' opinions, while there are policies that support energy access and use of electricity, a good number of households have no understanding of the policies. Respondents' perceptions about 
whether village/ward leaders encourage the use of energy efficiency appliances through different media such as radio, television, workshops revealed that 37 (I2.3\%) strongly disagree, 84(28\%) disagree, 35(II.7\%) neither agree nor disagree), 86(29\%) agree and $57(19 \%)$ strongly agree. The results indicate respondents do not agree on village leaders' efforts to encourage use of energy efficiency appliances in the wards, as seen from the data as well as respondents informal discussions during data collection.

Respondents' opinions about coordination between Members of Parliament (MP) and ward and village leaders about energy access and efficiency in the wards/villages indicated $\operatorname{Iog}_{3}(36.3 \%)$ strongly disagree, $65(21.7 \%)$ disagree, $57(19 \%)$ neither agree nor disagree, $59(20 \%)$ agree and $9(3 \%)$ strongly agree. The results indicate the interviewees consider there is lack of effective coordination between Members of Parliament (MP) and ward and village leaders about energy access and efficiency. The perceptions of the households on the availability of energy efficient appliances including solar panels, energy saving bulbs, cooking stoves in the market, revealed 36(12\%), 62(20.7\%), 50(16.7\%), I05 $35 \%$ and $46(\mathrm{I} 6 \%)$. The results indicate that energy efficient appliances are available in the market, but the extent of use is low which might be related to several factors including household income. Finally, involvement of households and other stakeholders in energy investment indicates the following, 6o(20\%), 88(29.3\%), 108(36\%), 32(10.7\%) and $\operatorname{II}(3.7 \%)$. Though there is a possibility for a village not to have received any investment in energy sector, still their disagreement on involvement in energy investment remains valid and thus, is a necessary input for energy decision making in the district.

Figure 3 presents the three categories of political-institutional barriers, namely lack of policy coordination, conflicting guidelines and political obstruction to energy access and efficiency in Mvomero district. The political obstruction constitutes efforts made by political and ward/village leaders to ensure enhanced access to renewable energy source and use of energy efficient appliances. On this question many respondents strongly disagreed on the aspect that the village leaders promote use of energy efficient appliances through different media including radios, television and newspapers (Fig. 3(a)). Also, questions on whether the current energy policy encourages households to use renewable energy and/or energy efficient appliances revealed that the majority of respondents agreed, which indicates availability of legal documents which need prompt enforcement at the village level. The lack of policy to coordinate use of renewable energy and energy efficient appliances i.e., how government plans and instruments work together to ensure energy access and use of energy efficient appliances in the district, indicates that the majority of households have no knowledge of relevant government plans and instruments that govern the use of energy and energy efficient appliances (Fig. 3(b)). In addition, universities dealing with training, research and consultancy in the energy field were found to provide little or no help to households on the use of alternative energy sources and energy efficient appliances. On the aspect of stakeholders' involvement in the wards energy investments, the study revealed that many respondents were neutral, which might be an indication of the lack of investment in their areas or that actually ward/village leaders do not involve them in various energy investments. Finally, there seem to be conflicting 
guidelines on energy access and efficiency in the district, as the majority of the respondents strongly disagreed that Members of Parliament (MP), village and ward leaders are well coordinated when handling energy access and efficiency issues including household use of energy efficient appliances for different social-economic activities (Fig. 3 (c)). On the aspect of village/ward regulations being very strict on energy access and use of energy efficient appliances, the majority of respondents were neutral or disagreed, which again might have more than one interpretation; either they are not aware of the regulations or actually available regulations are not strict in the sense that they are not well enforced at village/ward level.

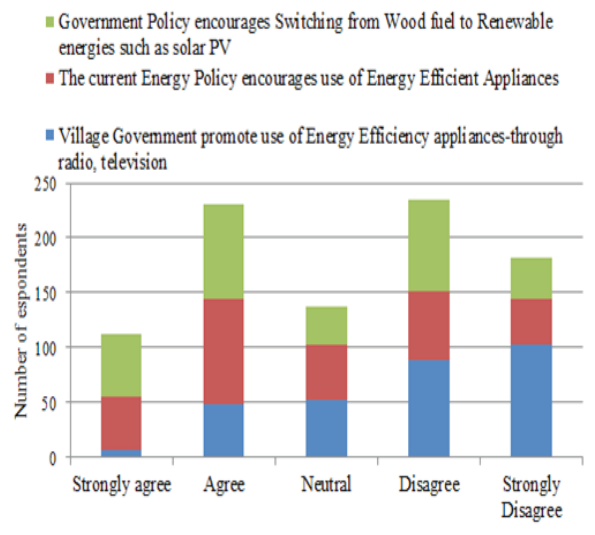

(a)

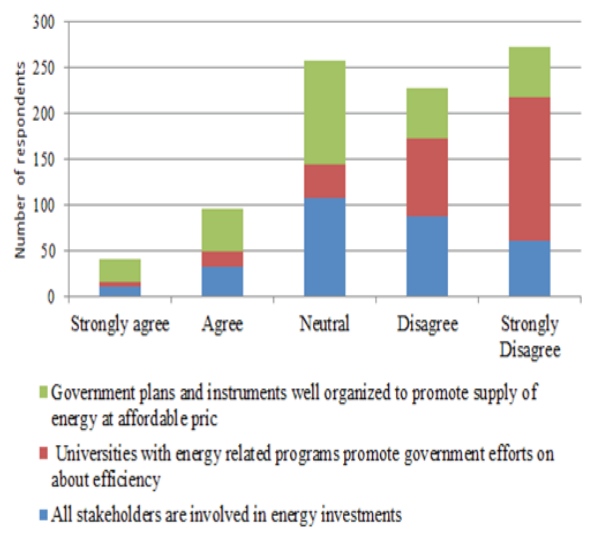

(b)

w The MP, Ward and Village Leaders are well coordinated when it come into energy access issues-political will

-Village Govemment Regulations are very strict on Energy Efficiency appliances - enforceability of laws

$=$ Good Coordination between different Government Agencies about energy efficiency-MP, Ward and village leaders

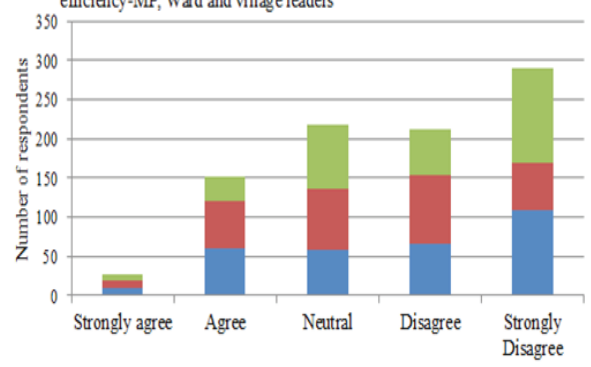

(a) Political obstruction on energy access and efficiency

(b) Lack of policy coordination on energy access and efficiency

(c) Conflicting guidelines about energy access and efficiency

(c)

Flgure 3: Political-institutional barriers to energy access and efficiency. 


\section{Conclusion and recommendations}

This article reports on a study on the dominant political-institutional barriers to energy access and efficiency in the five wards of Mvomero district as perceived by households living in the area. Political obstruction was considered to be the main factor hindering energy access and efficiency in the district. For example, effective enforcement of laws and legislation by different government agencies concerning energy access and use of energy efficient appliances is lacking or ward/village leaders do not speak the same language in relation to issues of increasing energy supply and access to energy efficient appliances. In one of the villages visited, households witnessed that despite their low level of income, they would have done better in terms of environmental conservation if they had been educated or informed about the need to shift from using wood to natural gas/electricity.

Based on the findings, the study identifies the need for a private public partnership model to enhance sustainable, reliable and affordable energy in terms of consistency monitoring and follow-up on emerging policy, regulations and laws. Also there is, so far, inadequate research on the role of political institutions in terms of energy access in rural Tanzania. In order to address this gap universities and training institutions dealing with energy issues should play a role, not only directly with villagers but also in training government officials and politicians as they are the political-institutional barriers that affect household energy use. In addition, government subsidies on appliances and electricity bills is encouraged to help households afford electricity and the purchase of energy saving appliances. Therefore the results of this study provide a useful and updated information for policy making and energy planning organs in Mvomero district on the critical barriers to energy access and efficiency. This in turn will help those organs to take remedial action.

\section{Acknowledgement}

This study was supported by the VLIR-UOS Programme GRE@T, Mzumbe University, Tanzania

\section{References}

Bertrand, S. L., Benhaddadi, M., Jegen, M., Pineau, P. O. (20I5). Political-institutional barriers to energy efficiency. Energy Strategy Reviews 8, 30-38.

Brew-Hammond, A. (20I0). Energy access in Africa: challenges ahead. Energy Policy 38, 29I-30I.

Colenbrander, S., Lovett, J., Abbo, M. S., Msigwa, C., M’Passi-Mabiala, B., Opoku, R. (2015). Renewable energy doctoral programmes in sub-Saharan Africa: A preliminary assessment of common capacity deficits and emerging capacity-building strategies. Energy Research and Social Science 5, 70-77.

Dawes, J. (2008). "Do data characteristics change according to the number of scale points used?" International Journal of Market Research, 50 (I), 6I-77.

Dawn, I. (2010). Structural Equations Modeling: Fit Indices, Sample Size, and Advanced Topics. Journal of Consumer Psychology 20, 90-98. 
Hair, J. F., Black, W. C., Babin, B. J., Tatham, R. L. (2006). Multivariate Data Analysis. New Jersey: Prentice Hall.

Harmelink, M., Nilsson, L. Harmsen, R. (2008). Theory based policy evaluation of 20 energy efficiency instruments, Energy Effic. I, I3I-I48.

Hartley, J., Betts, L. R. (2010). Four layouts and a finding: the effects of changes in the order of the verbal labels and numerical values on Likert-type scales. International Journal of Social Research Methodology, I3 (I), 17-27.

Hosier, R. H., Dowd, J. (I987). Household fuel choice in Zimbabwe: an empirical test of the energy ladder hypothesis. Resources and Energy 9(4), 347-36r.

IEA (2013). Transition to sustainable buildings: strategies and opportunities to 2050.

(2014). Energy Balances of non-OECD Countries 2014 [Online]. Paris, France: International Energy Agency. Available:/content/book/energy_bal_nonOECD 20I4-en http://dx.doi.org/Io.I787/energy_bal_non-oecd 20r4-en.

IEI (2017). Energy Efficiency: The need project. Intermediate Energy Infobook (IEI), 8408 Kao Circle, Manassas, VA 20110 I.800.875.5029.

IRENA (2014). Prospects for the African power sector. Abu Dhabi, United Arab Emirates: International Renewable Energy Agency; 2012. Available from http://www.irena.org/DocumentDownloads/Publications/Prospects for the African PowerSector. pdf.

Ismail, Z., Khembo, P. (2015). Determinants of energy poverty in South Africa. J. energy South. Afr. 26 (3), 66-78.

Jiang, R. H. I. (2012). Energy efficiency and conservation in an office building: a case study. International Journal of Energy Sector Management, 6(2), I75-I88.

Kabaka, K. T., Gwang'ombe, F. (2007). Challenges in small hydropower development in Tanzania: rural electrification perspective. International Conference on Small Hydropower-Hydro. Sri Lanka, 22-24.

Kichonge, B., John, G. R., Mkilaha, I. S. N. (2015). Modelling energy supply options for electricity generations in Tanzania. Journal of Energy in Southern Africa 26(3), 4I-57.

Lyakurwa, F. S., Mkuna, E. (2017). Dominant Factors for Energy Choice Decisions by Households in Tanzania: A Case Study of Selected Villages in Mvomero District. African Journal of Science, Technology, Innovation and Development, 2017, In progress.

MEM (2012). Power System Master Plan 2012 Update. Ministry of Energy and Minerals, Dar es Salaam.

OECD (20II). OECD Green Growth Studies: Energy, Organization for Economic Cooperation and Development and International Energy Agency, Paris, 20Ir.

_ (2012). OECD Environmental Outlook to 2050, OECD Publishing http://dx.doi.org/10.1787/9789264122246-en.

OECD/IEA (2014). Energy Efficiency Indicators: Essentials for Policy-making, Organization for Economic Cooperation and Development and International Energy Agency, Paris, 2014.

Reddy, K. N (2000). Energy and Social Issues: World Energy Assessment; Energy and the challenge of sustainability:. United Nations Development Program, 39-58

Sorrell, S., O'Malley, E., Schleich, J., Scott, S. (2004). The Economics of Energy Efficiency Barriers to Cost effective Investment, Edward Elgar, Cheltenham.

UN-HABITAT (2009). Tanzania Morogoro profile: Regional and Technical Cooperation Division. United Nations Human Settlements Programme.

United Nation (2005). Best Policy Practices for Promoting Energy Efficiency. A structured framework of best practices in policies to promote energy efficiency for climate change mitigation and sustainable development.

International Monetary Fund (IMF) (20II). National Strategy for Growth and Reduction of Poverty II (NSGRP II). Ministry of Finance and Economic Affairs, URT. 
URT (2013). 2012 population distribution and housing census: Population distribution by administrative areas. National Bureau of Statistics, Ministry of Finance Dar es Salaam.

(2016). National Five Year Development Plan 2016/17-2020/21.

Van der Horst, G. H., Hovorka A. J. (2008). Reassessing the "energy ladder": Household energy use in Maun, Botswana. Energy Policy 36, 3333-3344.

Weber, L. (1997). Some reflections on barriers to the efficient use of energy, Energy Policy 25, 833-835.

World Bank (2017). Energy Access Food and Agriculture: 2017 International Bank for Reconstruction and Development/the World Bank, Washington DC, ppi2. 